\title{
The Challenges, Opportunities and Countermeasures of Golf Clubs in China
}

\author{
Jing Rong \\ Foreign language dept., he bei Institute of P.E. \\ shijiazhuang, China \\ 736821030@qq.com
}

\begin{abstract}
This paper analyzed the challenges and opportunities faced by Chinese golf clubs in their current management and development, presenting countermeasures to take challenges, seize opportunities and seek development. After being researched by literature, analogical reasoning, expert interview and field survey, the paper put forward some countermeasures-build more public courses, reduce the prices and expand consumer groups; narrow differences between regions and adjust measures to local conditions; strengthen the talent and technology development of universities; accelerate cultural integration. Only in these ways, can we create the brilliant future for golf sport and industry in China.
\end{abstract}

Keywords- Challenges, Opportunities, Countermeasures, Golf Clubs in China

\section{INTRODUCTION}

In 2009, the International Olympic Committee passed a resolution that the golf sport will return to the Olympic Games in 2016, which made the people connected with golf sport in China wild with joy. They hoped that with the chance of helping golf in China which had been in troubles would breakthrough the bottleneck and step onto the road of healthy and sustainable development. But the dawn they wished hasn't appeared up to now. The problems besetting the golf development in China still remain fuzzy, controversial and uncertain, such as the establishment of specialized management mechanism and system, the improvement of management level, mass popularity and the training of professional players and so on. Therefore, the severe challenges still lie ahead.

\section{THE CHALLENGES ARE FACED BY CHINESE GOLF CLUBS}

A. Challenges of Chinese golf's noble-oriented position to masses' low consuming ability

At present, most domestic golf clubs are adopting membership. Usually the price of a membership card is at several hundreds of thousand Yuan or so. But China's urban resident per capita disposable income of 2012 is only 24,565 Yuan[1]. The gap between most working class' low income and the high cost and charges of golf sport has brought rigorous challenges to the running of golf clubs.

\author{
Lifei Han; Wei Song \\ Social P.E. dept., he bei institute \\ of P.E. \\ shijiazhuang, China \\ 446930112@qq.com; 357488842@qq.com
}

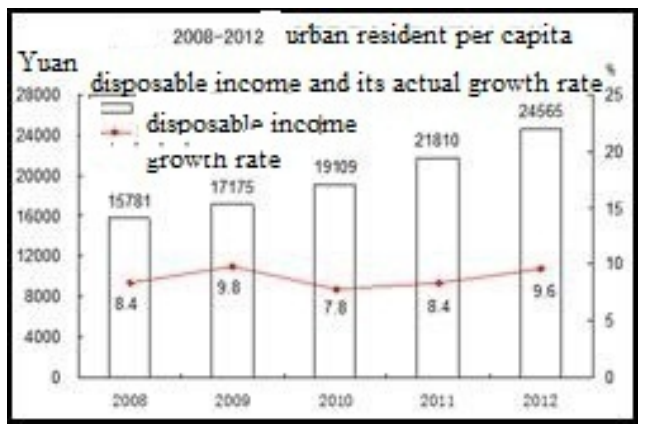

Figure 1. 2008-2012 URBAn Resident PeR CAPITA DisPosable INCOME AND ITS ACTUAL GROWTH RATE

\begin{tabular}{|c|c|c|c|}
\hline $\begin{array}{c}\text { Club/ } \\
\text { annual } \\
\text { membership } \\
\text { fee }\end{array}$ & $\begin{array}{c}\text { RMB } \\
\text { (individual) }\end{array}$ & $\begin{array}{l}\text { Club/ annual } \\
\text { Membership } \\
\text { fee }\end{array}$ & RMB \\
\hline $\begin{array}{c}\text { Mission } \\
\text { Hill }\end{array}$ & $\begin{array}{c}338,000 \\
\text { (Ruby) }\end{array}$ & Pine Valley & $1,500,000$ \\
\hline $\begin{array}{c}\text { Chung Shan } \\
\text { Hot Spring }\end{array}$ & 200,000 & $\begin{array}{l}\text { Tomson golf } \\
\text { club }\end{array}$ & $1,200,000$ \\
\hline Xuelianshan & 298,000 & Lakefacing & 208,000 \\
\hline Jinghui & 228,000 & Xishang Public & 35,000 \\
\hline JingHua & 320,000 & $\begin{array}{c}\text { Longgang } \\
\text { Public }\end{array}$ & $\begin{array}{c}9600 \\
\text { (weekday) }\end{array}$ \\
\hline
\end{tabular}

FIGURE 2. 2013 MEMBERSHIP CARD’s ANNUAL FEE IN GOLF CLUBS IN CHINA

CompComparing above two figures, we can see those private golf clubs' annual membership fees are just an astronomical figure to common people. Even those public courses' membership fees are still too expensive for the public. In fact in China, there are very few public golf courses, even the cheapest Longgang Public golf club's annual membership fee still accounts for $40 \%$ of their annual disposable income. Under the current situation that most Chinese are facing three big mountains-house, children's education and medical money, who will take out $40 \%$ annual income to pay for golf sport except those $20 \%$ richest people?

These data seem give us an impression that the future development of golf sport in China is facing a big problem, because most Chinese people haven't money to support it. 
But if you think in another way, just depend on those 20\% rich Chinese, that will be a very big population, 1.35 billion times $20 \%$, that will be 270 million people, it is still a very big number, nearly the population of entire America. That is also an enormous market. So expanding the consumer groups will be extremely important in developing golf in China.

The challenge of the uneven regional development of golf courses in China to the popularization of this sport

Seeing from the overall current distribution of Chinese golf courses, there are three states: Beijing, Shanghai and Guangdong are the most popular and the most mature regions for the golf games. The next are the economically developed coastal areas; the Northeast, Northwest and Southwest areas have relatively few courses; few provinces even don't have any golf courses at all. The distribution of the golf courses in China is almost consistent with the regional distribution of national economical development.

The extreme imbalance of the regional economical development in China led to the regional developmental imbalance of golf sport, consequently hindering the developmental process of Chinese golf industries.

\section{B. The challenge of the demanding golf talent market to the low level of current golf practitioners from colleges and training institutions}

Golf academic education and training institutions are novelties which have appeared in China in recent years. According to incomplete statistics, 50+ colleges and universities are offering majors related to golf. And there are also $800+$ golf educating and training institutions (including secondary vocational schools). Counting based on the theory that a normal golf course needs 350 practitioners , the talent gap of hundreds of golf clubs in China is more than 100 thousand. Seeing from appearance, the golf talent gap is immense, so its employment prospects ought to be brilliant. But it is not necessarily the case.

In domestic administrative field of golf clubs, the employers of golf clubs value the practical experience and social network, what they need are middle and top-level administrators. Although undergraduates have studied for 4 years in the universities, it is still impossible for them to become middle- or top-level administrators. If they start from the bottom of the posts, such as caddies, attendants or grass-workers, what are the advantages comparing with those farmers employed together with them at the same time?

Due to the above reasons, some golf major graduates left this field. According to 2011 Forward White Paper-Golf Industry Report, among those interviewed students, there were $43.9 \%$ to prefer working in golf industry when they graduate; $31.3 \%$ of respondents expressed they were not sure and 25\% students' answers were refusal. That means there are $56.3 \%$ students are potential leavers to golf industry.

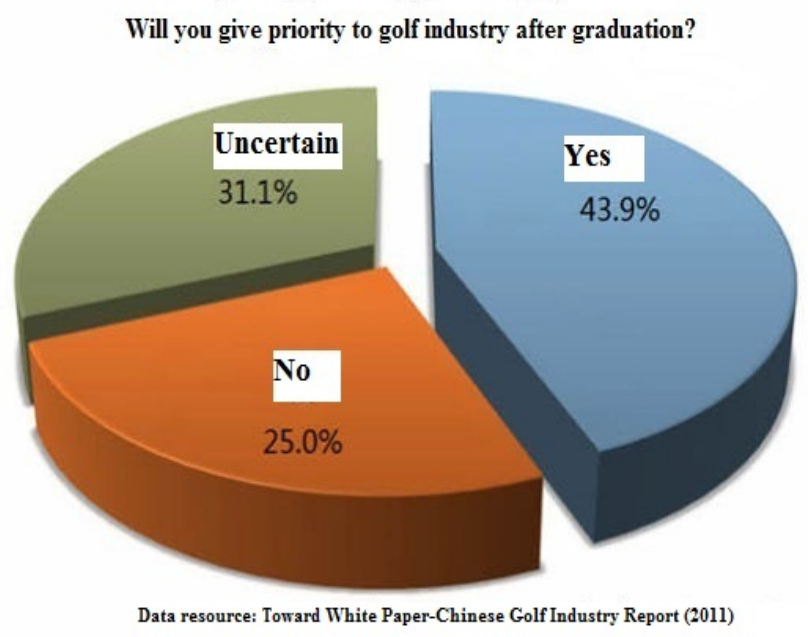

FIGURE 3. WILL YOU GIVE PRIORITY TO GOLF INDUSTRY AFTER GRADUATION?

\section{As a whole new lifestyle, golf is a challenge to Chinese traditional living customs}

There is a saying popular in China, the sound of chanting must be in India; the roar for football must be in Europe; and the sound of mahjong and counting money must be heard in China. The mahjong population in China is estimated over 100 million, of whom over tens of millions of people always play with big sum of money. It's easy for them to afford golf. However, the fact is China's golf population is only five million. Mahjong always makes people sit long. During playing time, because of players' focusing, they seldom move, which do harm to people's health a lot. But such an irritant gambling activity more than an entertainment, has been an indispensable activity in Chinese life for thousands of years. While golf sport which comes from western countries, an outdoor sport, making people return to nature and strengthen body. The cultural difference between Chinese and Western people makes it hard to drive those inveterate Chinese gamblers to golf courses.

\section{CHINESE GOLF IS ALSO FACING MORE OPPORTUNITIES}

\section{A. The annual increasing golf population has brought a huge market space for golf course construction}

According to the newly released Forward White Paper 2012, in 2012, there are 39 newly opened courses which include 747 holes in total; it is equivalent to forty-two 18hole golf courses. The net growth rate of facilities is $8.4 \%$, and of 18 -hole golf course is $8.1 \%$.The total rounds created by playing golf are $11,500,000$ rounds in the whole year, increased by 850,000 rounds, up about $8.0 \%$ over 2011 (in 2011, growth rate of the total rounds is 7.4\%).[2] It indicates that, domestic demand for consumption of golf is always in the growth, which has benefited and will keep on benefiting golf industry. 


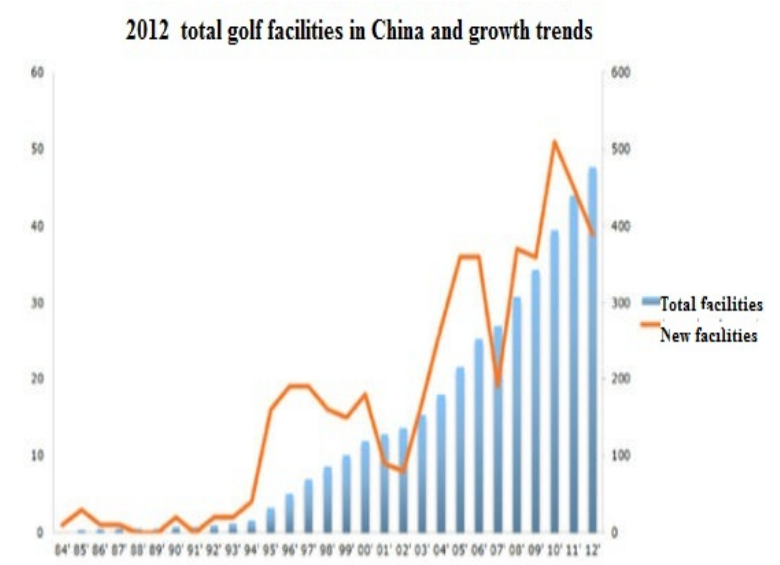

FIGURE 4. 2012 TOTAL GOLF FACILITIES IN CHINA AND GROWTH TRENDS

\section{B. The number of golf courses is far from meeting the} needs of Chinese economic development.

Golf industry's development is related to economic development closely. As long as it is an economically developed or rapidly developing country or region, the development of golf industry must be rapid. In 2000, the United States Golf Foundation has established three longrange targets of 2020 American golf industry development. The details as follows, the golf population will increase from the current 35 million to 55 million. The annual increase is 1 million. The number of played rounds will be increased from 518 million to 1 billion. The annual increase is 25 million rounds. Till 2020, golf sport will be expected to be as popular as American football in the United States. In 2000, the United States had more than 2500 golf courses. On the land area, it ranks first in the world.[3] Due to the shortage of land resources, Japanese golf industries have penetrated the United States of America. They have invested in constructing golf courses in the United States and started to manage them. In Taiwan, because of its rapid economic development, it has had 85 golf courses already. The golf course area accounts for $2 \%$ total area of Taiwan province. Therefore, comparing with America, 2500 golf courses/ 200 million people, China's 477 golf courses/ 1.37 billion people is far from meeting the needs of Chinese sustained and rapid economic development.

\section{The rapid development of international and domestic competitions}

The number of the international and domestic competitions sponsored and hosted by China Golf Association has tripled in the last two years and currently it is more than 120, including the HSBC champions and Volvo tournaments, Omega World Cup European tour, the PGA tour and the same Asian tours, LET the women's tour in Europe, the LPGA tour (microbag), etc., and the BMW new Masters will be hosted in 2012. The amount of the HSBC champions and omega World Club prize ranks the first in Asia, not including various types of games and activities held by the provinces, autonomous regions and municipality sports departments and local golf associations. Most of the world's top 10 golf players have been to China to participate in the competitions.

\section{Related industries have got promoted}

The industry chain derived from golf was formed step by step, including golf media, education, events, activities, golf expo industry, supplies, and equipment related to golf and manufacturing, etc. According to relevant data, nearly $80 \%$ of golf supplies in the world such as global medium and low-end equipment, ball bags, clothing, balls are produced in China. The greatest golf expo will be dominated by China Golf Association each year and held in Beijing and Guangzhou and other places.

China has become the most potential and vital place for golf in the world.

\section{COUNTERMEASURE RESEARCH OF GOLF DEVELOPMENT IN CHINA}

\section{A. Increase the construction of public golf courses,} change the price disadvantage, and expand the consumer groups

The high cost of Private golf courses kept most of golf enthusiasts away. Therefore, the construction of middle or low grade clubs, public courses and driving ranges should be increased in order to meet the basic needs of ordinary golf lovers, and at the same time they should be cautious not to conflict with the high-grade clubs' operation, but to help them to improve their brand images, and gradually forming a all-round consumption system with high-end golf clubs as a brand image, public golf courses serve the mass. The combination of high-end and low-end clubs will make golf sport under great development in China.

\section{B. Narrow differences between regions by multi-co} operations and adjust measures to local conditions

Beijing, Shanghai and Guangdong which have profound culture and great economic foundation are the most popular and mature places for golf development. Coastal economic developed regions are also the main support areas for China's economy, which showed a strong developmental momentum. While oppositely, in the Northeast, Northwest, Southwest and other regions, the golf courses are relatively fewer because of the slow economic development, even a few provinces have no golf courses. Regional imbalance of economic development is the direct cause of golf development imbalance, which has hindered the developmental process of golf sport in China.

In Northeast, Northwest, Southwest and other regions where economy develops slowly, the government should be publicized how golf industries will promote local economic development, improve the investment environment and increase tourism income. Meanwhile, these areas should adjust measures to local conditions and take advantages of local natural geographical features, for example, snow mountains in Northeast, deserts in Northwest, highlands in Southwest. It is very feasible to invest and finance actively and build some simplified, low standard public golf courses to meet the needs of the public, jointly promoting the 
coordinated development of golf sport and industries in these regions through multi- co operations.

\section{Starting golf talent training project, strengthening the talent and technical development in colleges and universities}

At present, the Chinese senior talents in golf management are basically from overseas. If Chinese golf industry wants developments, it has to be supported by human resources. Based on colleges and universities, China should make efforts to develop golf education, cultivate golf local talents, realize talent localization, and reduce costs. Through School-enterprise co-operation, the administrative staffs of golf clubs can do further study in schools. We also can make students practice in golf clubs and learn theoretical knowledge at the same time, which will benefit them in their command and improvement in their acquisition and enhancement of the knowledge they've learned in class. As for clubs, on the premise of guaranteeing quality and basic income, they should endeavor to promote golf industries, make full use of the resources of clubs and members to develop golf tourism, vacation, equipment sales, special restaurants and products.

\section{Accelerate cultural integration, expand new consumer groups}

It is very important to break the people's psychological and cultural obstacles if golf sport wants to get a wider range of developments in China. We should let people feel that golf culture is actually a part of Chinese culture and golf is not far away from us. Golfers in play always follow the etiquette and rules, without conceit, calm down, which is just consistent with the Chinese traditional culture of "peaceful heart helps your health." And golf game requires players to be self-disciplined, honesty, which is also in line with the values of Chinese culture.

In recent years, the female members of golf clubs are increasing all the time, especially some fashionable celebrities' joining in, which can bring more women to follow suit and join in golf sport.

Since 2009 golf was declared to return to the Olympics, the numbers of teenage golf players have risen sharply. In 2013, the most popular golfer is Guan TianLang, a 14-yearold "youngest golfer", " the youngest promotion golfer”, and "the first promoted Chinese golfer" in the US Masters. Believe it or not , there will be more youngsters to follow in his footsteps in joining in golf sport.

\section{CONCLUSION}

As is well known, China has become a sports powerful country because of the whole nation system. But the development of golf sport did not obtain any favors from this kind of system due to various reasons. And that has created all sorts of troubles in Chinese golf current developmental status. Golf was started in China relatively late and even now it is still in the stage of growth, which means golf will give birth to greater opportunities at the same time. We believe that through the effortful exploration of Chinese golf people and constant adjustment of developmental measures, it will be sure for Chinese golf sport to have a good prospect.

\section{REFERENCES}

[1]http://www.stats.gov.cn/tjgb/ndtjgb/qgndtjgb/t20130221_402874525.ht

[2] Cao Xiren, Recognition and Prospect, Golf Prospects Under the Background of Chinese Culture, September 25, 2011, http://sports.sina.com.cn.

[3] http://www.igolfyou.cn/article-21-1.html

[4] Dr. Michael Hurdzen, The Future of Golf in China, September 25, 2011, http://sports.sina.com.cn.

[5] Wang Jun, Li Zhicheng, et al, Forward White Paper of Golf.

[6] Ma Zongren, Golf Business Management [M] ,1st Ed., Tianjin Science and Technology Press, Sept. 2008.

[7] Mark Godfrey, Luo Yuanjun, Who Can Afford the Game of Golf?, China Today (Chinese version), August 2004.

[8] Yu Feng, Love of Golf. Brokerage ,2004-11

[9] Chen Jing, Golf Business Model and Innovative Research, Business Economy. August 2004.

[10] Wu Kexiang, Cultural Recognition and Golf Development, Special Zone Economy, Nov. 2004.

[11] Zhao Xiaolin, Cui Zhiyong, Motivation and Opportunities of Golf Industrialization Development, Market Modernization. February 2006.

[12]http://www.missionhillschina.com/zhCN/shenzhen/golf/membership/ruby_membership

[13] http://www.cshsgc.com.cn/Home/index.php/Member/membe

[14] http://www.gzgolf.net/

[15] http://www.jhgolf.cn/hyzq.htm

[16] http://www.jhgolf.cn/hyzq.htm

[17] http://sports.sina.com.cn/golf/course/bj/huabinclub/

[18] http://www.huagolf.com/client/course/details-1420.html

[19]http://www.lakefrontgolf.com/digital.asp?genusid=1373 